p-ISSN. 2086-9029

e-ISSN. 2654-5675

Vol. 22 No. 1, Hlm. 1-158, Juni 2020

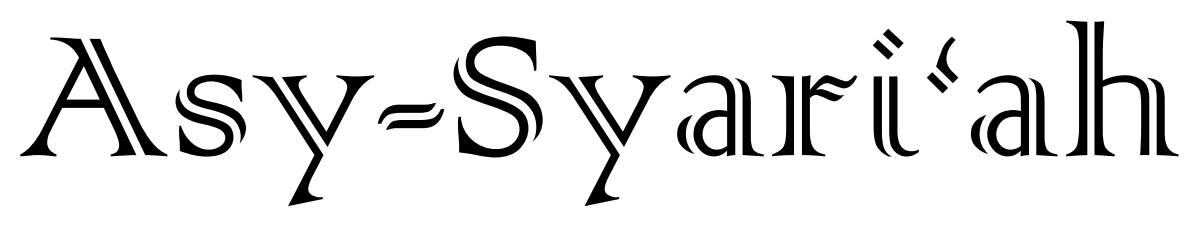

- Hukum Waris Islam Sebagai Instrumen Kepemilikan Harta

$(1-20)$ Hafidz Taqiyyudin

- Komparasi Metodologi Hukum Aliran Maqasidi dan Aliran Syakli

$(21-34)$ Hudzaifah Achmad Qotadah

- Reinterpretasi Hak Ijbar dalam Hukum Perkawinan Islam di Keluarga $(35-50)$ Pesantren

Kudrat Abdillah

- Dimensi Kondisionalitas dan Fleksibilitas Al-Quran bagi Implementasi $(51-66)$ Fatwa DSN-MUI tentang Produk Bank Syariah

Ahmad Hasan Ridwan, Asep Rahmat

- Validitas Hadis Tidak Ada Kisas bagi Orang Tua yang Membunuh Anaknya

Moh. Ahsanuddin Jauhari, Enceng Arif Faizal, Syahrul Anwar, Atep Mastur, Deden Najmudin

- Penguatan Resolusi Konflik Berbasis Tradisi Sunnah Nabi

Alamsyah

- Sistem Perencanaan, Pelaksanaan dan Pengawasan Industri Halal di Wilayah Provinsi Banten

Akhyakudin, Suja'i, Muhammad Abduh

- Reformulation of Family Legal in Indonesia for Female Maslahah

Wahidullah, Murniati, Yushinta Eka Farida, Jumaiyah

- The Concept and Aplication of Covenant in Financing Gold Pawn By Sharia Bank in West Java

Neni Nuraeni, Dewi Sulastri, Zulbaidah

- Tinjauan Sosiologi Hukum tentang Kepatuhan Masyarakat terhadap ( $147-158)$ Undang-Undang Wakaf

Deden Effendi

FACULTY OF SHARIA AND LAW

STATE ISLAMIC UNIVERSITY SUNAN GUNUNG DJATI BANDUNG-INDONESIA IN COLLABORATION WITH ASOSIASI SARJANA SYARIAH INDONESIA 


\section{Asy-Syari'ah}

Volume 22, Number 1, 2020

\section{EDITOR-IN-CHIEF}

Ine Fauzia

\section{EDITORIAL BOARD}

Sofyan al-Hakim, UIN Sunan Gunung Djati Bandung, Indonesia Deni Kamaludin Yusup, UIN Sunan Gunung Djati Bandung, Indonesia Meria Utama, Fakultas Hukum Univrsitas Sriwijaya, Indonesia Dewi Mayaningsih, UIN Sunan Gunung Djati Bandung, Indonesia Andrey Sujatmiko, Fakultas Hukum Universitas Trisakti, Jakarta, Indonesia Hetty Hassanah, Universitas Komputer Indonesia, Indonesia

\section{PEER-REVIEWERS}

Muhammad Irfan Helmy, IAIN Salatiga, Semarang, Indonesia Ahmad Ali Nurdin, UIN Sunan Gunung Djati Bandung Tajul Arifin, UIN Sunan Gunun Djati Bandung, Indonesia Mohamad Anton Athoillah, UIN Sunan Gunung Djati Bandung, Indonesia Mrs. Renny Supriyatni, Universitas Padjadjaran, Indonesia Ahmad Tholabi Karlie, UIN Syarif Hidayatullah Jakarta, Indonesia Ija Suntana, UIN Sunan Gunung Djati Bandung, Indonesia Zezen Zaenal Mutaqin, University of California, Los Angeles, United States Ahmad Fathonih, UIN Sunan Gunung Djati Bandung, Indonesia Rahman Syamsuddin, Universitas Islam Negeri Alauddin Makassar, Indonesia

\section{PROOFREADER/DESIGN COVER}

Nanang Sungkawa

\section{LAYOUT EDITOR}

Opik Rozikin

Asy-Syari' ah has been accredited based on the determination of Director General of Research and Development Strengthening, Ministry of Research, Technology and Higher Education of Republic of Indonesia, No. 14/E/KPT/2019 (valid until 2023). 


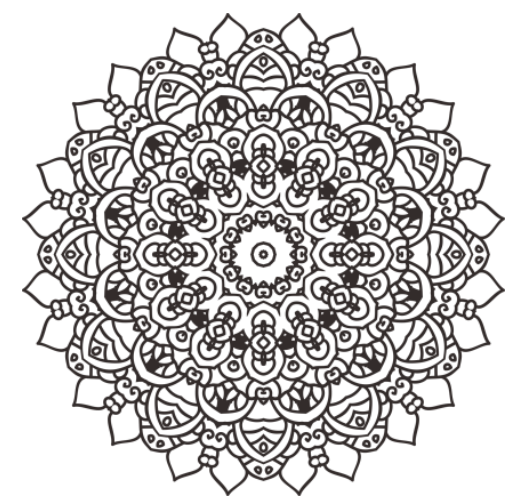

\title{
VALIDITAS HADIS TIDAK ADA KISAS BAGI ORANG TUA YANG MEMBUNUH ANAKNYA
}

\section{${ }^{1}$ Moh. Ahsanuddin Jauhari, ${ }^{2}$ Enceng Arif Faizal, ${ }^{3}$ Syahrul Anwar, ${ }^{4}$ Atep Mastur, ${ }^{5}$ Deden Najmudin \\ 1,2,3,4,5Fakultas Syariah dan Hukum UIN Sunan Gunung Djati Bandung, Email: ahsanjauhari@uinsgd.ac.id, encengariffaizal@uinsgd.ac.id,} syahrulanwar@uinsgd.ac.id, atep.mastur@uinsgd.ac.id, deden.najmudin@uinsgd.ac.id

\begin{abstract}
One of mawâni' al-qishâsh is that victims are part of the perpetrators. That is, parents who kill their children can not be sanctioned qishâsh. This is based on the hadith of the Prophet which states that, "lâ yuqâd al-wâlid bi waladihî" and "anta wa mâluk li abîka". This opinion is held by Abû Hanîfah, al-Syâfi 'î, and Ahmad ibn Hanbal. This study aims to determine the validity of the first hadith which is used as a basis so that it can be a guideline whether the hadith is acceptable or not. The method used is the takhrîj method. The results showed that the hadith had a variety of matan who were narrated by at least seven mudawwin. This shows that the hadith is narrated in meaning rather than lafaz. There are at least eleven lanes of the shilshilah sanad found, but none of them have the quality of shahîh because there are weaknesses in each of the lane of the sanad. Therefore, if seen from the validity requirements of the hadith, the value of the hadith is weak.
\end{abstract}

Keywords: kill, qisas barrier, qisas, validity of hadith 


\begin{abstract}
Abstrak: Salah satu penghalang sanksi kisas adalah korban merupakan bagian dari pelaku. Maksudnya, orang tua yang membunuh anaknya tidak dapat dikenai sanksi kisas. Hal ini didasarkan atas hadis Nabi SAW yang menyatakan bahwa, "lâ yuqâd alwâlid bi waladihî" dan "anta wa mâluk li abîka". Pendapat ini dipegang oleh Abû Hanîfah, al-Syâfi î̀, dan Ahmad ibn Hanbal. Penelitian ini bertujuan untuk mengetahui validitas hadis pertama yang dijadikan landasan sehingga dapat menjadi pegangan apakah hadis tersebut dapat diterima atau tidak. Metode yang digunakan adalah metode takhrîj. Hasil penelitian menunjukkan bahwa hadis tersebut memiliki redaksi yang beragam yang diriwayatkan setidaknya oleh tujuh mudawwin. Ini menunjukkan bahwa hadis tersebut diriwayatkan secara makna bukan lafaz. Setidaknya ada sebelas jalur silsilah sanad yang ditemukan, namun semuanya tidak ada yang memiliki kualitas shahîh karena pada setiap jalur silsilah sanadnya ada kelemahan. Oleh karena itu, jika dilihat dari persyaratan kesahihan hadis, maka hadis tersebut nilainya lemah.
\end{abstract}

Kata-kata Kunci: membunuh, penghalang kisas, sanksi kisas, validitas hadis 


\section{Pendahuluan}

Sanksi pokok bagi pelaku pembunuhan sengaja adalah kisas, sebagaimana termaktub dalam Alquran surat al-Baqarah ayat 178. Allah SWT telah mewajibkan kepada mereka yang beriman untuk melaksanakan sanksi kisas dalam hal pembunuhan. Para ulama kemudian memahaminya bahwa pembunuhan tersebut adalah pembunuhan sengaja, walaupun mereka berbeda pendapat dalam hal merumuskan kualifikasinya. Para ulama pun berbeda pendapat dalam penerapan sanksi kisas tersebut jika dihubungkan dengan rukun dan syarat yang menyertai pembunuhan tersebut. Di antaranya dalam hal-hal yang menghalangi kisas (mawâni al-qishâsh).

Abû Hanîfah, al-Syâfi î̀, dan Ahmad ibn Hanbal berpendapat bahwa sanksi kisas tidak dapat dilaksanakan atau terhalang jika korban yang dibunuh merupakan bagian dari pelaku. Maksudnya, jika ada orang tua yang membunuh anaknya dengan sengaja, maka sanksi kisas menjadi terhalang dan tidak bisa dilaksanakan. Orang tua di sini dapat diartikan dengan ayah dan seterusnya ke atas (kakek) atau ibu dan seterusnya ke atas (nenek). Demikian juga dengan pengertian anak, maksudnya adalah anak dan seterusnya ke bawah (cucu). Pendapat kedua yang dikemukakan oleh Mâlik menyatakan bahwa orang tua yang membunuh anaknya dengan sengaja, maka sanksinya adalah kisas. Menurut Mâlik, ayah atau ibu yang membunuh anaknya dengan sengaja, misalnya menebas leher anak atau merobek perutnya dengan sengaja, maka sanksinya adalah kisas. Kecuali, jika pembunuhan itu disertai syubhat, misalnya ayah atau ibu dalam kerangka mendidik, memukul anaknya yang mengakibatkan kematian, maka tidak ada kisas baginya. ${ }^{1}$

Pendapat pertama yang dipegang oleh ketiga ulama tersebut di atas didasarkan atas dua hadis. Hadis pertama menyatakan bahwa, "lâ yuqâd al-wâlid bi waladihî", artinya orang tua tidak bisa dituntut kisas karena membunuh anaknya. Hadis kedua menyatakan bahwa, "anta wa mâluk li abîka", artinya kamu dan hartamu adalah milik ayahmu. Hadis pertama jelas menghalangi kisas, sedangkan hadis kedua walaupun tidak jelas menghalangi kisas, namun isinya menghalangi kisas karena kepemilikan ayah terhadap anaknya. Hal tersebut menjadi syubhat yang dapat menghalangi kisas karena ada kaidah yang menyatakan hindari hudud jika ada syubhat (dar'v al-hudûd bi al-syubuhât). ${ }^{2}$

Tulisan ini akan mencoba mengkritisi validitas hadis yang dijadikan landasan ketiga ulama di atas. Hal ini penting karena persoalan sanksi pembunuhan ini merupakan hal yang berat. Menurut Endang Soetari Ad., kualitas hadis merupakan salah satu tolok ukur dari ke-hujjah-an hadis. Hujjah adalah kapasitas hadis sebagai manhaj amaliyah syarî‘ah, bayân Alquran dan dalîl mustanbat. ${ }^{3}$

${ }^{1}$ 'Abd al-Qâdir 'Awdah, al-Tasyrî' al-Jinâîi al-Islâmî Muqâranan bi al-Qânûn al-Wadl î̀, (Bayrût: Mu'assasat al-Risâlat, 1992), Juz II, hlm. 115-117; A Djazuli, Fiqh Jinayah: Upaya Menanggulangi Kejahatan dalam Islam, (Jakarta: PT Raja Grafindo Persada, 2000), hlm. 137.

2 'Abd al-Oâdir 'Awdah, al-Tasyrî' al-Jinâîîl-Islâmî Muqâranan bi al-Oânûn al-Wadl î̀, Juz Il, hlm. 115.

${ }^{3}$ Endang Soetari Ad., Pengembangan Syarah dan Kritik Hadits dengan Metode Takhrij pada Universitas alAzhar Mesir, (Bandung: Amal Bakti Press, 2010), hlm. 38. 


\section{Metodologi}

Validitas hadis ini akan diuji dengan metode takhrîj. Adapun langkahnya adalah dengan mencari asal usul hadis tersebut dalam kitab-kitab hadis mashâdir al-ashliyat. Kemudian para rawi yang menjadi shilshilat al-sanad-nya dikritisi dengan menggunakan kitab-kitab rijâl al-hadîts. Data jarh wa ta 'dîl para perawi kemudian menentukan kesahihan haids yang diukur dengan kriteria kesahihan hadis. ${ }^{4}$

\section{Hasil dan Pembahasan \\ Riwâyat bi al-Ma'nâ}

Hadis tentang orang tua tidak dapat dikisas karena membunuh anaknya terdapat dalam beberapa kitab hadis mashâdir al-ashliyah. Setidaknya ada tujuh kitab hadis mashâdir al-ashliyah yang meriwayatkannya, yaitu: (1) Al-Mushannaf fí al-Ahâdits wa alAtsâr karya Abû Bakar ibn Abî Syaibah, 'Abdullâh ibn Muhammad ibn Ibrâhîm ibn 'Utsmân ibn Khawâsitî al- 'Abasî (w. 235 H). (2) Musnad al-Imâm Ahmad ibn Hanbal karya Abû 'Abdullâh Ahmad ibn Hanbal ibn Hilâl ibn Asad al-Syaybânî (w. 241 H); (3) Sunan alDârimî karya Abû Muhammad 'Abdullâh ibn 'Abd al-Rahmân ibn al-Fadll ibn Bahrâm ibn 'Abd al-Shamad al-Dârimî (w. 255 H); (4) Sunan ibn Mâjah karya Ibn Mâjah Abû 'Abdullâh Muhammad ibn Yazîd al-Qazwaynî (w. 273 H); (5) al-Jâmi'al-Kabîr - Sunan al-Turmudzî karya Muhammad ibn 'Îsâ ibn Sawrah ibn Mûsâ ibn al-Dlahâk al-Turmudzî (w. 279 H); (6) Musnad al-Bazâr dikenal juga dengan al-Bahr al-Zukhar karya Abû Bakar Ahmad ibn 'Amr ibn 'Abd al-Khâliq ibn Khalâd ibn 'Ubaydillâh al-Bazâr (w. 292 H); (7) Sunan alDâruqutnî karya Abû al-Hasan 'Alî ibn 'Umar ibn Ahmad ibn Mahdî ibn Mas' ûd ibn alNu'mân ibn Dînar al-Baghdâdî al-Dâruqutnî (w. $385 \mathrm{H}$ ).

Hadis tersebut juga diriwayatkan dengan berbagai matan hadis. Setidaknya ada lima matan hadis, yaitu: lâ yuqtâl al-wâlid bi al-walad diriwayatkan oleh al-Turmudzî́, alBazâr ${ }^{6}$, al-Dâraqutnîn, Ibn Abî Syaybah ${ }^{8}$ dan Ibn Mâjah"; lâ yuqtâl bi al-walad al-wâlid

\footnotetext{
${ }^{4}$ Mahmûd Thahhân, Ushûl al-Takhrîj wa Dirâsat al-Asânid, (Bayrût: Dâr al-Qurân al-Karîm, 1978), hlm.1213. Kitab hadis mashâdir al-ashliyah adalah kitab-kitab hadis yang ditulis oleh mudawwin/penulisnya disertai dengan sanadnya secara lengkap sampai kepada sumber pertamanya, misalnya: Kitab Muwatha' Mâlik, Musnad Ahmad, Shahîh Bukhârî, Shahîh Muslim, Sunan al-Dâruquthnî, dan lain-lain. Kitab rijâl al-hadîts adalah kitab-kitab yang menghimpun biografi rawi dan menjelaskan jarh wa ta'dil-nya (kecacatan dan keadilanya), misalnya: kitab Tahdzîb al-Kamâl fi Asmấi al-Rijâl yang disusun oleh al-Mizzî, kitab Tahdzîb al-Tahdzî́b yang disusun oleh Ibn Hajar al-'Asqalânî, dan lain-lain.

${ }^{5}$ Muhammad ibn 'T̂sâ ibn Sawrah ibn Mûsâ ibn al-Dlahâk al-Turmudzî (selanjutnya disebut al-Turmudzî), al-Jâmi 'al-Kabîr Sunan al-Turmudzi. (Bayrut: Dâr al-Gharb al-Islâmî, 1996), Muhaqqiq: Basyâr 'Awad Ma 'ûf, Juz III, hlm. 71.

${ }^{6}$ Abû Bakar Ahmad ibn 'Amr ibn 'Abd al-Khâliq ibn Khalâd ibn 'Ubaydillâh al-Bazâr, Musnad al-Bazâr (alBahr al-Zukhar). (al-Madînah al-Munawwarah: Maktabah al-'Ulûm wa al-Hukm, 2009), Muhaqqiq: Mahfuzh alRahmân Zaynullâh, Juz XI, hlm. 114 .

${ }^{7}$ Abû al-Hasan 'Alî ibn 'Umar ibn Ahmad ibn Mahdî ibn Mas ûd ibn al-Nu'mân ibn Dînar al-Baghdâdî alDâruqutnî (selanjutnya disebut al-Dâruqutnî), Sunan al-Dâruqutnî, (Bayrût-Lubnân: Mu'assasat al-Risâlat, 2004), Juz IV, hlm. 168.
} 
diriwayatkan oleh Ibn Mâjahici lâ yuqâd bi al-waladi al-wâlid diriwayatkan oleh alDârimî $^{11}$; lâ yuqâd al-wâlid min waladihi diriwayatkan oleh Ahmad ibn Hanbal ${ }^{12}$; dan lâ yuqâd al-wâlid bi al-waladi al-wâlid diriwayatkan oleh al-Turmudzî ${ }^{13}$ dan al-Dâraqutnî. ${ }^{14}$ Perbedaan redaksi hadis tersebut dapat dilihat pada tabel 1 di bawah ini. Ini menunjukkan bahwa hadis tentang tidak ada kisas bagi orang tua yang membunuh ankanya adalah hadis yang diriwayatkan secara makna bukan secara lafaz.

Tabel 1

Matan Hadis dan Perawinya

\begin{tabular}{|c|l|l|}
\hline No & \multicolumn{1}{|c|}{ Redaksi } & \multicolumn{1}{c|}{ Mudawwin/Perawi } \\
\hline 1 & lâ yuqtâl al-wâlid bi al-walad & $\begin{array}{l}\text { al-Turmudzî, al-Bazâr, al-Dâraqutnî, Ibn Abî } \\
\text { Syaybah, dan Ibn Mâjah }\end{array}$ \\
\hline 2 & lâ yuqtâl bi al-walad al-wâlid & Ibn Mâjah \\
\hline 3 & lâ yuqâd bi al-waladi al-wâlid & al-Dârimî \\
\hline 4 & lâ yuqâd al-wâlid min waladihi & Ahmad ibn Hanbal \\
\hline 5 & lâ yuqâd al-wâlid bi al-waladi & al-Turmudzî dan al-Dâraqutnî \\
\hline
\end{tabular}

Sumber: Olah data penulis, 2020.

\section{Silsilah Sanad dan Kesahihannya}

Hadis lâ yuqtâl al-wâlid bi al-walad

Hadis lâ yuqtâl al-wâlid bi al-walad diriwayatkan oleh lima perawi, yaitu: alTurmudzî, al-Bazâr, al-Dâraqutnî, Ibn Abî Syaybah, dan Ibn Mâjah. Silsilah sanadnya apat dilihat pada gambar 1 di bawah ini:

${ }^{8}$ Abû Bakar 'Abdullâh ibn Muhammad ibn Ibrâhîm ibn 'Utsmân ibn Khawâsitî al-'Abasî lbn Abî Syaybah, Al-Mushannaf fi al-Ahâdits wa al-Atsâr, (Riyâdl: Maktabah al-Rusydî, 2004), Muhaqqiq: Hamad bin 'Abdullah alJum 'ah dan Muhammad ibn Ibrâhîm, Juz V, hlm. 451.

${ }^{9}$ Ibn Mâjah Abû 'Abdullâh Muhammad ibn Yazîd al-Qazwaynî (selanjutnya disebut Ibn Mâjah), Sunan ibn Mâjah, (t.t.: Dâr Ihyâ al-Kutub al- 'Arabiyah, t.th.), Muhaqqiq: Muhammad Fuad 'Abd al-Bâqî, Juz Il, hlm. 888.

${ }^{10}$ lbid.

${ }^{11}$ Abû Muhammad 'Abdullâh ibn 'Abd al-Rahmân ibn al-Fadll ibn Bahrâm ibn 'Abd al-Shamad al-Dârimî, Sunan al-Dârimî, (Mamlakah al-Su 'ûdiyah al-'Arabiya: Dâr al-Mughnî, 2000), Juz III, hlm. 1522.

${ }^{12}$ Abû 'Abdullâh Ahmad ibn Hanbal ibn Hilâl ibn Asad al-Syaybânî, Musnad al-Imâm Ahmad ibn Hanbal. (Mesir: Mu'assasah Qurtubah, t.th.), Juz I, hlm. 257.

${ }^{13}$ al-Turmudzî, al-Jâmi al-Kabîr Sunan al-Turmudzi. Juz III, hlm. 70.

${ }^{14}$ al-Dâruqutnî, Sunan al-Dâruqutnî, (Bayrût-Lubnân: Mu'assasat al-Risâlat, 2004), Juz IV, hlm. 168. 
Gambar 1

Silsilah sanad hadis lâ yuqtâl al-wâlid bi al-walad

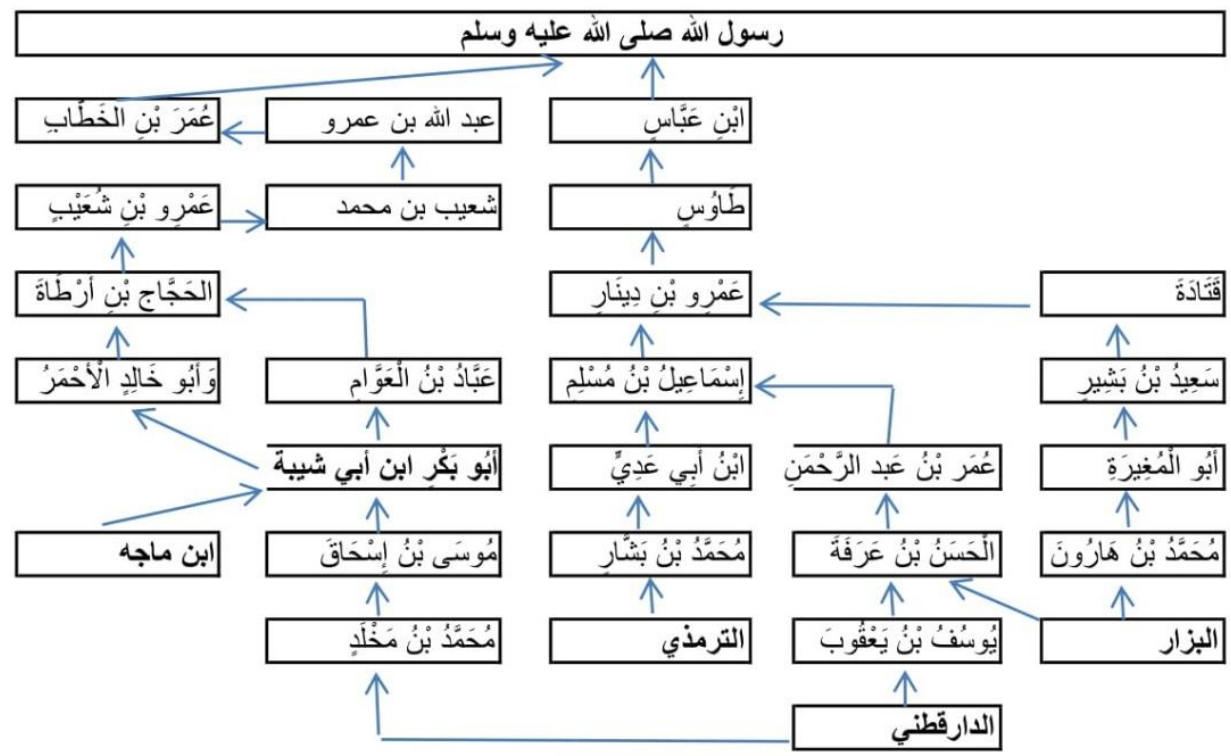

Sumber: Olah data penulis, 2020.

Jumlah rawi yang terlibat dalam hadis dengan redaksi lâ yuqtâl al-wâlid bi alwalad ada 27 rawi sebagaimana terlihat pada gambar 1 di atas. Setelah ditelusuri dengan menggunakan kitab-kitab rijâl al-hadîts, maka terlihat jarh wa ta dîl para rawi sebagaimana ada pada tabel 2 di bawah ini:

Tabel. 2

Jarh wa Ta 'dîl Râwî Silsilah Sanad Hadis lâ yuqtâl al-wâlid bi al-walad

\begin{tabular}{cll}
\hline No & \multicolumn{1}{c}{ Rawi } & Jarh wa Ta dîl \\
\hline 1 & Ibn 'Abbâs & shahâbat ('âdil) \\
\hline 2 & 'Umar ibn Khattab & shahâbat ('âdil) \\
\hline 3 & Thâwus ibn Kaysân al-Yamanî & tsiqat $^{15}$ \\
\hline 4 & 'Amr ibn Dînâr & tsiqat $^{16}$ \\
\hline 5 & Ismâ'il ibn Muslîm & dla î́f $^{17}$ \\
\hline 6 & Ibn Mâjah & al-hafizh $^{18}$ \\
\hline 7 & Muhammad ibn Ibrâhîm ibn Abî 'Addî & tsiqat $^{19}$ \\
\hline 8 & Muhammad ibn Bashâr & tsiqat shadûq shâlih $^{20}$ \\
\hline
\end{tabular}

${ }^{15}$ Yûsuf ibn 'Abd al-Rahmân ibn Yûsuf, Abû al-Hajâj, Jamâl al-Dîn ibn al-Zakî Abî Muhammad al-Qadlâ îalKalbî al-Mizzî (selanjutnya disebut al-Mizzî), Tahdzîb al-Kamâl fí Asmấi al-Rijâl, (Bayrût: Mu'assasat al-Risâlat, 1980), Juz XIII, hlm. 360.

${ }^{16}$ Ahmad ibn 'Ali bin Hajar al- 'Asqalânî (selanjutnya disebut al-'Asqalânî), Tahdzîb al-Tahdzîb, (Bayrut: Muassasat al-Risalat, t.th.), Juz VIII, hlm. 30; al-Mizzî, Tahdzîb al-Kamâl fí Asmấi al-Rijâl, Juz XXII, hlm. 10.

${ }^{17}$ al- 'Asqalânî, Tahdzîb al-Tahdzîb, Juz I, hlm. 332; Al-Mizzî, Tahdzîb al-Kamâl fí Asmâ'i al-Rijâl, Juz III, hlm. 201.

${ }^{18}$ Al-Mizzî, Tahdzîb al-Kamâl fí Asmâ'i al-Rijâl, Juz XXVII, hlm. 40-41.

${ }^{19}$ Al- 'Asqalânî, Tahdzîb al-Tahdzîb, Juz IX, hlm. 12, Al-Mizzî, Tahdzîb al-Kamâl fí Asmâ'i al-Rijâl, Juz XXIV, hlm. 321. 
Moh. Ahsanudin, Enceng,Syahrul, Atep, Deden, Validitas Hadis Tidak Ada Kisas Bagi ... | 73

\begin{tabular}{|c|c|c|}
\hline No & Rawi & Jarh wa Ta dîl \\
\hline 9 & Al-Turmudzî & al-hafizh $^{21}$ \\
\hline 10 & Qatâdah ibn Di'âmah & tsiqat $^{22}$ \\
\hline 11 & Sa îd ibn Basyîr & dla îf, munkar, laysa bi al-qawîn ${ }^{23}$, shadûqq ${ }^{24}$ \\
\hline 12 & Abû al-Mughîrah & tsiqat, shadûq ${ }^{25}$ \\
\hline 13 & 'Umar ibn 'Abd al-Rahmân & tsiqat, shadûq ${ }^{26}$ \\
\hline 14 & Muhammad ibn Hârûn & tsiqat, shadûq ${ }^{27}$ \\
\hline 15 & Al-Hasan ibn 'Arafah & tsiqat, shâlih ${ }^{28}$ \\
\hline 16 & Al-Bazâr & al-hafizh $^{29}$ \\
\hline 17 & Yûsuf ibn Ya'qûb & dla $i \hat{i}^{30}$ \\
\hline 18 & Al-Dâraqutnî & tsiqat $^{3^{1}}$ \\
\hline 19 & 'Abdullâh ibn 'Amr ibn 'Âsh & shahâbat ('âdil) \\
\hline 20 & Syu’ayb ibn Muhammad & $t_{\text {siqat }}{ }^{2}$ \\
\hline 21 & 'Amar ibn Syu'ayb & tsiqat $^{33}$ \\
\hline 22 & Al-Hajjah ibn Arthâh & shadûq, katsîr al-khata' wa tadlîs ${ }^{34}$, shadûq yadlis ${ }^{35}$ \\
\hline 23 & Abû al-Khâlid al-Ahmâr & tsiqat, shadûq, laysa bi hujjah ${ }^{36}$ \\
\hline 24 & 'Abbâd ibn al-Awwâm & tsiqat, shadûq \\
\hline 25 & Abû Bakar ibn Abî Syaybah & tsiqat al-hâfizh ${ }^{38}$ \\
\hline 26 & Mûsâ ibn Ishhâq & tsiqat $^{39}$ \\
\hline 27 & Muhammad ibn Makhlad & tsiqat $^{40}$ \\
\hline
\end{tabular}

Sumber: Olah data penulis, 2020.

${ }^{20}$ Al- 'Asqalânî, Tahdzîb al-Tahdzîb, Juz IX, hlm. 72; Al-Mizzî, Tahdzîb al-Kamâl fí Asmấi al-Rijâl, Juz XXIV, hlm. 517.

${ }^{21}$ Al-Mizzî, Tahdzîb al-Kamâl fí Asmấi al-Rijâl, Juz XXVI, hlm. 252.

${ }^{22}$ Al-'Asqalânî, Tahdzîb al-Tahdzîb, Juz VIII, hlm. 355; Al-Mizzî, Tahdzî̉ al-Kamâl fî Asmấi al-Rijâl, Juz XXIII, hlm. 515 .

${ }^{23}$ Al- 'Asqalânî, Tahdzîb al-Tahdzîb, Juz IV, hlm. 8.

${ }^{24}$ Al-Mizzî, Tahdzîb al-Kamâl fí Asmâ'i al-Rijâl, JuzX, hlm. 351.

${ }^{25}$ Al-'Asqalânî, Tahdzîb al-Tahdzîb, Juz VI, hlm. 370.

${ }^{26}$ Ibid., Juz VII, hlm. 474.

${ }^{27}$ Ibid., Juz IX, hlm. 493.

${ }^{28}$ Al-Mizzî, Tahdzîb al-Kamâl fi Asmấi al-Rijâl, Juz VI, hlm. 201.

${ }^{29}$ Abû Bakar ibn Ahmad ibn 'Alî ibn Tsâbit ibn Ahmad ibn Mahdî al-Khatîb al-Baghdâdî, Tarîkh Baghdâd. (Bayrût: Dâr al-Kutub al- 'llmiyah, 1996), Juz V, hlm. 94-95.

${ }^{30}$ Syams al-Dîn Abû 'Abdullâh Muhammad ibn Ahmad ibn 'Utsmân al-Dzahabî (selanjutnya disebut alDzahabî), Mîzân al-I'tidâl fi Naqd al-Rijâl, (Bayrût: Dâr al-Ma 'rifah, 1963), Juz IV, hlm. 475.

${ }^{31}$ al-Dzahabi, Siyar A'lâm al-Nubalâ', (al-Qahirah: Dâr al-Hadîts, 2006), Juz XII, hlm. 416.

${ }^{32}$ Al- 'Asqalânî, Tahdzîb al-Tahdzîb, Juz IV, hlm. 356; Al-Mizzî, Tahdzîb al-Kamâl fi Asmâ'i al-Rijâl, Juz XII, hlm. 535 .

${ }^{33}$ Al- 'Asqalânî, Tahdzîb al-Tahdzî̉, Juz VIII, hlm. 49-50.

${ }^{34}$ Ibid., Juz II, hlm. 196-197.

${ }^{35}$ Al-Mizzî, Tahdzîb al-Kamâl fî Asmấi al-Rijâl, Juz V, hlm. 425-426.

${ }^{36}$ Ibid., Juz XI, hlm. 396-397.

${ }^{37}$ Ibid., Juz XIV, hlm. 143.

${ }^{38}$ Ibid., Juz XVI, hlm. 39.

${ }^{39}$ Syams al-Dîn Abû 'Abdullâh Muhammad ibn Ahmad ibn 'Utsmân al-Dzahabî, Târîkh al-Islâm, (t.t.: Dâr al-Gharb al-Islâmî, 2003), Juz Vl, hlm. 1058.

${ }^{40}$ Khayr al-Dîn ibn Mahmûd ibn Muhammad ibn 'Alî ibn Fâris al-Zarkalî, al-A'lâm. (t.t.: Dâr al-'Ilm li alMalâyîn, 2002), Juz VII, hlm. 93. 
Berdasarkan data pada tabel 2 di atas tampak bahwa ada beberapa rawi yang dijarh oleh para ulama hadis, yaitu: Sa îd ibn Basyîr, Al-Hasan ibn 'Arafah, Al-Hajjah ibn Arthâh, dan Abû al-Khâlid al-Ahmâr. Rawi-rawi tersebut justru menjadi sanad penghubung kepada Nabi SAW. Hadis yang diriwayatkan oleh Ibnu Mâjah, Ibnu Abî Syaybah dan al-Dâruqutnî melalui Al-Hajjah ibn Arthâh dalam satu tabaqah (Gambar 1). Para ulama hadis menilai Al-Hajjah ibn Arthâh ini dengan shadûq, katsîr al-khata' wa tadlîs. Ini artinya bahwa keadilan rawi Al-Hajjah ibn Arthâh tidak disepakati. Kelemahannya adalah melakukan tadlis yaitu mengganti rawi lemah yang menjadi jalur sanadnya dengan rawi lain yang adil. la mengganti rawi yang bernama Muhammad ibn 'Ubaydillâh al- 'Arzamî yang menurut para ulama hadis dinilai matrûk, dengan rawi lain bernama 'Amr ibn Syu'ayb, kemungkinan termasuk hadis ini..$^{41}$ Karenanya, hadis yang diriwayatkan Ibnu Mâjah dan Ibnu Abî Syaybah melalui Al-Hajjah ibn Arthâh dinilai dla îf (lemah). Terlebih sanad pada riwayat Ibnu Mâjah ada rawi yang bernama Abû al-Khâlid al-Ahmâr. Ada ulama hadis yang menilainya laysa bi hujjah, artinya tidak dapat dijadikan pegangan. ${ }^{42}$

Hadis yang diriwayatkan oleh al-Turmudzî dan al-Dâruqutnî melalui rawi Ismâ'îl ibn Muslîm dalam satu tabaqah. Para ulama hadis menilai Ismâ'îl ibn Muslîm dla 'îfł3 Karenanya, hadis yang diriwatkan oleh al-Turmudzî dan al-Dâruqutnî dinilai lemah. Terlebih hadis yang diriwayatkan oleh al-Dâruqutnî, selain melalui rawi Ismâ'îl ibn Muslîm, ada rawi yang bernama Yûsuf ibn Ya'qûb. Para ulama hadis menilainya rawi yang lemah. ${ }^{44}$ Sementara hadis yang diriwayatkan oleh al-Bazâr, ada rawi yang bernama Sa 'îd ibn Basyîr. Para ulama hadis menilainya dla 'îf, munkar, laysa bi al-qawî, ${ }^{45}$ walaupun ada ulama yang menilainya shadûq. ${ }^{46}$ Namun demikian karena ada ulama yang mencacatkannya, maka hadis ini menjadi lemah. Dengan demikian, hadis dengan redaksi lâ yuqtâl al-wâlid bi al-walad tidak ada yang shahîh, karena persyaratan kesahihan hadisnya tidak terpenuhi yaitu perawinya harus adil. Menurut Nûr al-Dîn 'Itr, hadis shahîh adalah hadis yang bersambung sanad-nya yang dinukil oleh râwi yang adil dan dlâbit dari râwi yang adil dan dlâbit juga sampai kepada puncaknya, tidak ada syâdz (kejanggalan) dan 'illat (cacat)" ${ }^{47}$

Hadis lâ yuqtâl bi al-walad al-wâlid

Hadis lâ yuqtâl bi al-walad al-wâlid hanya diriwayatkan oleh satu perawi, yaitu Ibnu Mâjah. Silsilah sanadnya dapat dilihat pada gambar 2. Jumlah rawi yang terlibat dalam hadis dengan redaksi ini ada tujuh. Enam rawi telah dijelaskan jarh wa ta dîl-nya pada

${ }^{41}$ Al- 'Asqalânî, Tahdzîb al-Tahdzîb, Juz II, hlm. 196-197; Al-Mizzî, Tahdzîb al-Kamâl fí Asmấi al-Rijâl, Juz V, hlm. 425-426.

${ }_{42}$ Al-Mizzî, Tahdzîb al-Kamâl fí Asmâ'i al-Rijâl, Juz XI, hlm. 396-397.

${ }^{43}$ Al- 'Asqalânî, Tahdzîb al-Tahdzîb, Juz I, hlm. 332; Al-Mizzî, Tahdzîb al-Kamâl fí Asmâ'i al-Rijâl, Juz III, hlm. 201.

${ }^{44}$ al-Dzahabî, Mîzân al-I'tidâl fí Naqd al-Rijâl, Juz IV, hlm. 475.

${ }^{45}$ Al- 'Asqalânî, Tahdzîb al-Tahdzîb, Juz IV, hlm. 8.

${ }^{46}$ Al-Mizzî, Tahdzîb al-Kamâl fi Asmâ'i al-Rijâl, JuzX, hlm. 351.

${ }^{47}$ Nûr al-Dîn 'Itr, Manhaj Naqdfí 'Ulûm al-Haditts, (Damsyiq: Dâr al-Fikr, 1979), hlm. 242. 
tabel 2 di atas, tinggal dua rawi yang bernama Suwayd ibn Sa'îd dan 'Alî ibn Mushir. Para ulama hadis menilai Suwayd ibn Sa îd shadûq ${ }^{48}$ dan tsiqat. ${ }^{49}$ Demikian juga 'Alî ibn Mushir dinilai oleh para ulama hadis sebagai rawi tsiqat. ${ }^{50}$ Akan tetapi dalam silsilah sanad ini masih melalui rawi yang bernama Ismâ îl ibn Muslîm yang nilai lemah oleh para ulama hadis. ${ }^{51}$ Karenanya hadis ini pun shahîh, karena persyaratan kesahihan hadisnya tidak terpenuhi yaitu perawinya harus adil.

\section{Gambar 2}

Silsilah sanad hadis lâ yuqtâl bi al-walad al-wâlid

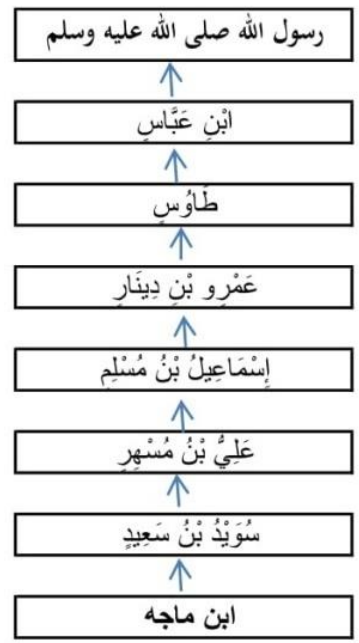

Sumber: Olah data penulis, 2020.

Hadis lâ yuqâd bi al-waladi al-wâlid

Hadis lâ yuqâd bi al-waladi al-wâlid hanya diriwayatkan oleh satu perawi, yaitu alDârimî. Silsilah sanadnya dapat dilihat pada gambar 3. Jumlah rawi yang terlibat dalam hadis dengan redaksi ini ada enam. Lima rawi telah dijelaskan jarh wa ta dîl-nya pada tabel 2 di atas, tinggal satu rawi yang bernama Ja 'far ibn 'Awn. Para ulama hadis menilai Ja far ibn 'Awn dengan rawi tsiqat. ${ }^{52}$ Namun, sama dengan hadis yang diriwayatkan oleh Ibn Mâjah di atas, ada rawi yang bernama Ismâ îl ibn Muslîm, sehingga kedudukan hadisnya pun lemah.

${ }^{48}$ Al- 'Asqalânî, Tahdzîb al-Tahdzîb, Juz IV, hlm. 273.

${ }^{49}$ Al-Mizzî, Tahdzîb al-Kamâl fi Asmâ'i al-Rijâl, Juz XII, hlm. 250.

${ }^{50}$ Al-'Asqalânî, Tahdzîb al-Tahdzîb, Juz VII, hlm. 383; Al-Mizzî, Tahdzîb al-Kamâl fi Asmâ'i al-Rijâl, Juz XXI, hlm. 138.

${ }^{51}$ Al-'Asqalânî, Tahdzîb al-Tahdzîb, Juz I, hlm. 332; Al-Mizzî, Tahdzîb al-Kamâl fí Asmâ'i al-Rijâl, Juz III, hlm. 201.

${ }^{52}$ Al- 'Asqalânî, Tahdzîb al-Tahdzî̉, Juz II, hlm. 101; Al-Mizzî, Tahdzîb al-Kamâl fí Asmấi al-Rijâl, Juz V, hlm. 72-73. 
Gambar 3

Silsilah sanad hadis lâ yuqâd bi al-waladi al-wâlid

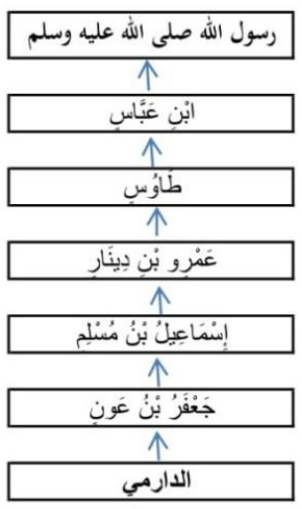

Sumber: Olah data penulis, 2020.

Hadis lâ yuqâd al-wâlid min waladihi dan lâ yuqâd al-wâlid bi al-waladi

Hadis lâ yuqâd al-wâlid min waladihi diriwayatkan oleh al-Turmudzî dan alDâruqutnî, sedangakan hadis lâ yuqâd al-wâlid bi al-waladi hanya diriwayatkan oleh Ahmad ibn Hanbal sebagaiman terlihat pada gambar 4 . Ada 32 rawi yang terlibat dalam hadis ini. Sebagian besar rawi telah dijelaskan jarh wa ta 'dîl-nya sebagaimana pada tabel 2 di atas. Sisanya dapat dilihat pada tabel 3.

\section{Gambar 4}

Silsilah sanad hadis lâ yuqâd al-wâlid min waladihi dan lâ yuqâd al-wâlid bi al-waladi

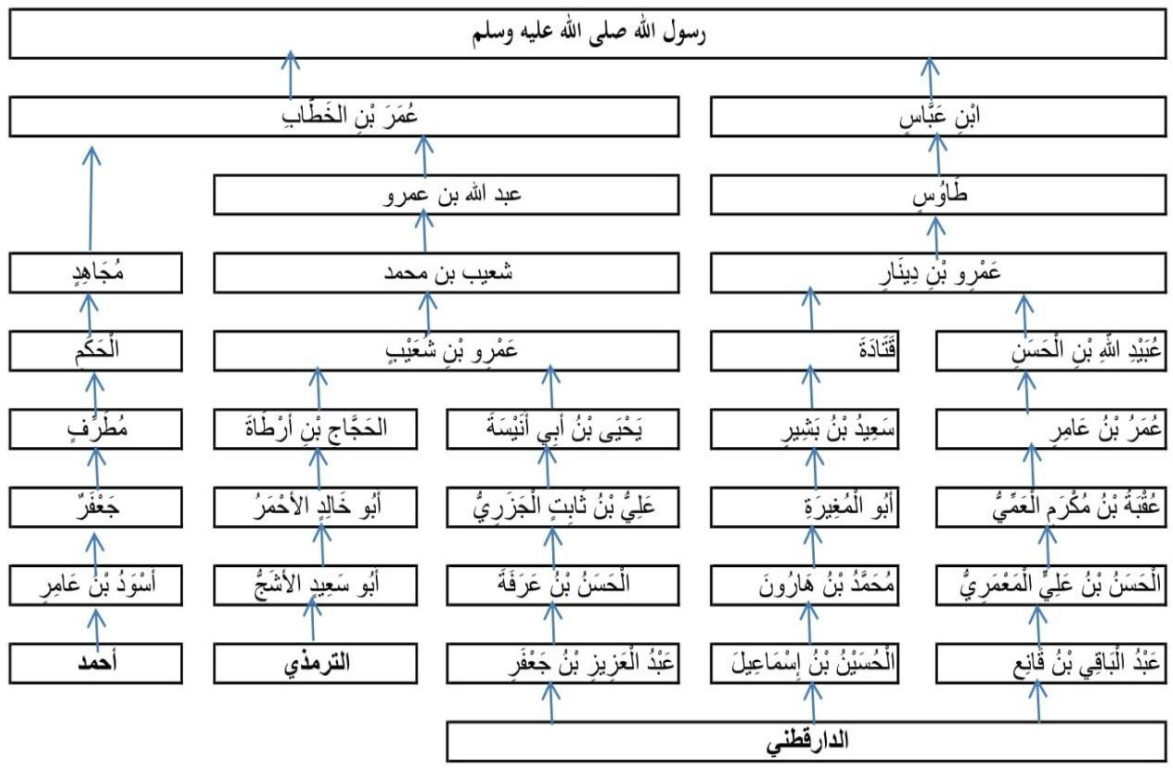

Sumber: Olah data penulis, 2020. 
Tabel 3

Jarh wa Ta 'dîl Râwî Silsilah Sanad Hadis lâ yuqâd al-wâlid min waladihi dan lâ yuqâd al-wâlid bi al-waladi

\begin{tabular}{|c|c|c|}
\hline No & Rawi & Jarh wa Ta dîl \\
\hline 1 & Mujâhid ibn Jabar & tsiqat $^{53}$ \\
\hline 2 & Al-Hakam ibn 'Utaybah & $t^{1}$ siqat ${ }^{54}$ \\
\hline 3 & Mutharrif ibn Tharîf & tsiqat $^{55}$ \\
\hline 4 & Ja far ibn Jiyâd & shadûq yatasyayyu , ${ }^{6}$ shadûq syi ${ }^{457}$ \\
\hline 5 & Aswad ibn 'Âmir & tsiqat $^{8}$ \\
\hline 6 & Ahmad ibn Hanbal & al-hafizh ${ }^{59}$ \\
\hline 7 & Abû Sa îd al-Asyajj & tsiqat $^{60}$ \\
\hline 8 & Yahyâ ibn Abî Unaysah & dla îfjiddan, matrûk ${ }^{61}$ \\
\hline 9 & 'Ali ibn Tsâbit al-Jazarî & shadûq rubama akhta, dla $i^{1 f^{62}}$ \\
\hline 10 & ‘Abd al- 'Azîz ibn Ja 'far ibn Bakar & $t_{\text {siqat }}$ t3 $^{3}$ \\
\hline 11 & Al-Husayn ibn Ismâ'îl & shadûq ${ }^{64}$ \\
\hline 12 & 'Ubaydillâh ibn al-Hasan & tsiqat $^{65}$ \\
\hline 13 & 'Umaribn 'Âmir & tsiqat, syaykh shâlih, shadûq, dla îif, ${ }^{66}$ laysa bihi ba's, dla îît \\
\hline 14 & 'Uqbah ibn Makram al-'Ammî & tsiqat $^{68}$ \\
\hline 15 & Al-Hasan ibn ‘Alîal-Ma 'mârî & tsiqat, $^{69}$ shadûq $^{70}$ \\
\hline 16 & 'Abd al-Bâqî ibn Qâni' & dla $i f^{71}$ \\
\hline 17 & Ja'far ibn 'Awn & tsiqat $^{72}$ \\
\hline
\end{tabular}

Sumber: Olah data penulis, 2020.

53 Al- Asqalânî, Tahdzîb al-Tahdzîb, Juz X, hlm. 42-44; Al-Mizzî, Tahdzîb al-Kamâl fí Asmấi al-Rijâl, Juz XXVIII, hlm. 233. hlm. 118.

${ }^{54}$ Al- 'Asqalânî, Tahdzîb al-Tahdzîb, Juz II, hlm. 432; Al-Mizzî, Tahdzîb al-Kamâl fí Asmâ'i al-Rijâl, Juz VIII,

${ }^{55}$ Al- 'Asqalânî, Tahdzîb al-Tahdzîb, Juz VIII, hlm. 172-173; Al-Mizzî, Tahdzîb al-Kamâl fí Asmâ'i al-Rijâl, Juz XXVIII, hlm. 64-65.

${ }^{56}$ Al-'Asqalânî, Tahdzîb al-Tahdzîb, Juz II, hlm. 93.

${ }^{57}$ Al-Mizzî, Tahdzîb al-Kamâl fí Asmâ'i al-Rijâl, Juz V, hlm. 40.

${ }^{58}$ Al- 'Asqalânî, Tahdzîb al-Tahdzîb, Juz I, hlm. 340; Al-Mizzî, Tahdzîb al-Kamâl fí Asmấi al-Rijâl, Juz III, hlm. 227.

${ }^{59}$ Al-'Asqalânî, Tahdzîb al-Tahdzîb, Juz I, hlm. 72.

${ }^{60}$ Ibid., Juz V, hlm. 236-237; Al-Mizzî, Tahdzîb al-Kamâl fí Asmâ'i al-Rijâl, Juz XV, hlm. 29.

${ }^{61}$ Al- 'Asqalânî, Tahdzîb al-Tahdzîb, Juz XI, hlm. 183; Al-Mizzî, Tahdzîb al-Kamâl fi Asmâ'i al-Rijâl, Juz XXXI, hlm. 225-226.

${ }^{62}$ Al-'Asqalânî, Tahdzîb al-Tahdzîb, Juz VII, hlm. 288-289.

${ }^{63}$ Abû Bakar ibn Ahmad ibn 'Alî ibn Tsâbit ibn Ahmad ibn Mahdî al-Khatîb al-Baghdâdî, Tarîkh Baghdâd. (Bayrût: Dâr al-Kutub al-'Ilmiyah, 1996), Juz X, hlm. 454.

64 al-Dzahabî, Târîkh al-Islâm, (t.t.: Dâr al-Gharb al-Islâmî, 2003), Juz VII, hlm. 589.

${ }^{65}$ Al- 'Asqalânî, Tahdzîb al-Tahdzîb, Juz VII, hlm. 7; Al-Mizzî, Tahdzîb al-Kamâl fí Asmấi al-Rijâl, Juz IX, hlm. 24 .

${ }^{66}$ Al-'Asqalânî, Tahdzîb al-Tahdzîb, Juz VII, hlm. 467.

${ }^{67}$ Al-Mizzî, Tahdzîb al-Kamâl fí Asmâ'i al-Rijâl, Juz XXI, hlm. 405.

${ }^{68}$ Ibid., Juz XX, hlm. 225.

${ }^{69}$ Al-'Asqalânî, Tahdzîb al-Tahdzîb, Juz II, hlm. 302.

${ }^{70}$ Al-Mizzî, Tahdzîb al-Kamâl fí Asmâ'i al-Rijâl, Juz VI, hlm. 258.

${ }^{71}$ al-Baghdâdî, Tarîkh Baghdâd, Juz XII, hlm. 357.

${ }^{72}$ Al- 'Asqalânî, Tahdzîb al-Tahdzîb, Juz II, hlm. 101; Al-Mizzî, Tahdzîb al-Kamâl fí Asmâ'i al-Rijâl, Juz V, hlm. 
Hadis lâ yuqâd al-wâlid bi al-waladi yang diriwayatkan oleh Ahmad, dilihat dari keadilan rawi, tampaknya tidak bermasalah, karena rawi yang menjadi silsilah sanadnya dinilai adil semuanya, namun dilihat dari sisi ketersambungan sanad, menurut para ulama hadis, Mujâhid itu tidak pernah menerima hadis dari 'Umar ibn Khattab, sehingga hadis ini terputus atau disebut dengan hadis munqati'. Ibnu Katsîr dalam kitab Musnad al-Fârûq menjelaskan bahwa ketika ada hadis dari Mujâhid yang menyandarkan kepada 'Umar ibn Khattab, maka hadis ini adalah hadis munqati' karena Mujâhid tidak pernah mendengar dan melihat 'Umar ibn Khattab, bahkan ulama hadis lainnya mengingkarinya dengan pengingkaran yang keras. ${ }^{73}$ Dengan demikian hadis ini menjadi lemah karena tidak memenuhi persyaratan kesahihan hadis dari sisi ketersambungan sanad.

Sementara hadis lâ yuqâd al-wâlid bi al-waladi yang diriwayatkan oleh alDâruqutnî, ada 3 jalur sebagaimana terlihat pada gambar 3. Jalur pertama 'Abd al-Bâqî ibn Qâni' dan seterusnya ke atas. Silsilah sanad pada jalur pertama ini ada 2 rawi yang dinilai lemah yaitu 'Abd al-Bâqî ibn Qâni' dan 'Umar ibn 'Amîr. Para ulama hadis menilai 'Abd al-Bâqî ibn Oâni' dla 'îf.74 Sementara 'Umar ibn 'Amîr dinilai sebagai rawi tsiqat, syaykh shâlih, shadûq, dla 'îff, laysa bihi ba's, dla îff. ${ }^{76}$ Menurut kaidah, apabila jarh dan ta dill berkumpul, maka jarh didahulukan daripada ta 'iî. ${ }^{77}$ Dengan demikian, hadis yang diriwayatkan oleh al-Dâruqutnî jalur pertama ini lemah karena ada dua tabaqah rawi yang lemah.

Silsilah sanad jalur kedua melalui rawi al-Hasan ibn Ismâ'îl dan seterusnya ke atas. Pada jalur kedua ini, ada rawi yang bernama Sa î̀ ibn Basyîr. Rawi ini dinilai lemah oleh para ulama hadis sebagai mana telah dijelaskan sebelumnya. Dengan demikian hadis dari jalur kedua pun dinilai lemah. Silsilah sanad jalur ketiga melalui rawi 'Abd al- 'Azîz ibn Ja'far ibn Bakar dan seterusnya ke atas. Pada jalur ini terdapat rawi yang bernama Yahyâ ibn Unaysah. Para ulama hadis menilainya sebagai rawi dla îf jiddan (sangat lemah), matrûk (ditinggalkan) ${ }^{78}$ dla î́f jiddan, matrûk. ${ }^{79}$ Dengan demikian hadis pada jalur ketiga ini pun dinilai lemah atau dla îf.

\section{Simpulan}

Berdasar hasil dan pembahasan dapat disimpulkan bahwa hadis lâ yuqtâl al-wâlid bi al-walad; lâ yuqtâl bi al-walad al-wâlid; lâ yuqâd bi al-waladi al-wâlid; lâ yuqâd al-wâlid min waladihi; dan lâ yuqâd al-wâlid bi al-waladi al-wâlid tentang tidak ada sanksi kisas

${ }^{73}$ Abû al-Fidâ' Ismâ îl ibn 'Umar Ibnu Katsîr, Musnad al-Fârûq Amîr al-Mu'minîn Abî Hafash 'Umar ibn Khattab. (Mesir: Dâr al-Falâh, 2009), Juz II, hlm. 252.

${ }^{74}$ al-Baghdâdî, Tarîkh Baghdâd, Juz XII, hlm. 357.

${ }^{75}$ Al- 'Asqalânî, Tahdzîb al-Tahdzîb, Juz VII, hlm. 467.

${ }^{76}$ Al-Mizzî, Tahdzîb al-Kamâl fí Asmâ'i al-Rijâl, Juz XXI, hlm. 405.

77 Ayat Dimyati, Pengantar Studi Sanad Hadits, (Bandung: Fakultas Syari'ah, 1997, hlm. 30.

${ }^{78}$ Al- 'Asqalânî, Tahdzîb al-Tahdzîb, Juz Xl, hlm. 183.

${ }^{79}$ Al-Mizzî, Tahdzîb al-Kamâl fí Asmâ'i al-Rijâl, Juz XXXI, hlm. 225-226. 
bagi orang tua yang membunuh anaknya diriwayatkan secara makna bukan lafaz. Setidaknya ada sebelas jalur silsilah sanad yang ditemukan, namun semuanya tidak ada yang memiliki kualitas shahîh karena pada setiap jalur silsilah sanadnya ada kelemahan. Oleh karena itu, jika dilihat dari persyaratan kesahihan hadis, maka hadis tersebut nilainya lemah.

\section{DAFTAR PUSTAKA}

'Asqalânî. al-, Ahmad bin 'Ali bin Hajar. Tahdzîb al-Tahdzîb, Bayrut: Muassasat al-Risalat. (t.th.)

'Awdah, 'Abd al-Qâdir. al-Tasyrî' al-Jinâî al-Islâmî Muqâranan bi al-Qânûn al-Wadl'î. Bayrût: Mu'assasat al-Risâlat. 1992.

Baghdâdî. al-, Abû Bakar ibn Ahmad ibn 'Alî ibn Tsâbit ibn Ahmad ibn Mahdî al-Khatîb. Tarîkh Baghdâd. Bayrût: Dâr al-Kutub al-' Ilmiyah. 1996.

Bazâr. al-, Abû Bakar Ahmad ibn 'Amr ibn 'Abd al-Khâliq ibn Khalâd ibn 'Ubaydillâh. Musnad al-Bazâr (al-Bahr al-Zukhar). al-Madînah al-Munawwarah: Maktabah al'Ulûm wa al-Hukm. Muhaqqiq: Mahfuẓ al-Rahmân Zaynullâh. (w. 292 H). (1409 H / $1988 \mathrm{M})$.

Dârimî. al-,. Abû Muhammad 'Abdullâh ibn 'Abd al-Rahmân ibn al-Fadll ibn Bahrâm ibn 'Abd al-Shamad. Sunan al-Dârimî, Mamlakah al-Su'ûdiyah al-'Arabiya: Dâr alMughnî. (w. 255 H). (1421 H/2000 M).

Dâruqutnî. al-, Abû al-Hasan 'Alî ibn 'Umar ibn Ahmad ibn Mahdî ibn Mas' v̂d ibn alNu'mân ibn Dînar al-Baghdâdî. Sunan al-Dâruqutnî. Bayrût - Lubnân: Mu'assasat al-Risâlat. (w. $385 \mathrm{H})$. (2004).

Dimyati, Ayat. Pengantar Studi Sanad Hadits. Bandung: Fakultas Syari'ah. 1997.

Djazuli, A. Fiqh Jinayah: Upaya Menanggulangi Kejahatan dalam Islam. Jakarta: PT Raja Grafindo Persada. (t.th)

Dzahabî. al-, Syams al-Dîn Abû 'Abdullâh Muhammad ibn Ahmad ibn 'Utsmân. Târîkh alIslâm. t.t.: Dâr al-Gharb al-Islâmî. 2003.

-----. Mîzân al-I 'tidâl fî Naqd al-Rijâl. Bayrût: Dâr al-Ma 'rifah. 1963.

----. Siyar A'lâm al-Nubalâ', al-Qahirah: Dâr al-Hadîts. v

Ibn Abî Syaybah, Abû Bakar 'Abdullâh ibn Muhammad ibn Ibrâhîm ibn 'Utsmân ibn Khawâsitî al-'Abasî. Al-Mushannaf fí al-Ahâdits wa al-Atsâr (Riyâdl: Maktabah alRusydî. Muhaqqiq: Hamad bin 'Abdullah al-Jum 'ah dan Muhammad ibn Ibrâhîm. (w. $235 \mathrm{H})$. (1425 H/2004 M).

Ibnu Katsîr, Abû al-Fidâ' Ismâ'îl ibn 'Umar. Musnad al-Fârûq Amîr al-Mu'minîn Abî Hafash 'Umar ibn Khattab. Mesir: Dâr al-Falâh. 2009. 
'Itr, Nûr al-Dîn. Manhaj Naqd fí 'Ulûm al-Hadîts, Damsyiq: Dâr al-Fikr. 1979.

Mizzî. al-, Yûsuf ibn 'Abd al-Rahnân ibn Yûsuf, Abû al-Hajâj, Jamâl al-Dîn ibn al-Zakî Abî Muhammad al-Qadlâ'î al-Kalbî. Tahdzîb al-Kamâl fî Asmâ'i al-Rijâl. Bayrût: Mu'assasat al-Risâlat. 1980.

Qazwaynî. al-, Ibn Mâjah Abû 'Abdullâh Muhammad ibn Yazîd. Sunan ibn Mâjah t.t.: Dâr Ihyâ al-Kutub al-' Arabiyah. Muhaqqiq: Muhammad Fuad 'Abd al-Bâqî. (w. 273 H). (t.th.).

Syaybânî. al-, Abû 'Abdullâh Ahmad ibn Hanbal ibn Hilâl ibn Asad. Musnad al-Imâm Ahmad ibn Hanbal. Mesir: Mu'assasah Qurtubah. (w. 241 H). (t.th.).

Soetari Ad, Endang. Pengembangan Syarah dan Kritik Hadits dengan Metode Takhrij pada Universitas al-Azhar Mesir. Bandung: Amal Bakti Press. (2010).

Thahhân, Mahmûd. Ushûl al-Takhrîj wa Dirâsat al-Asânid, Bayrût: Dâr al-Qurân al-Karîm. 1978.

Turmudzî. al-, Muhammad ibn 'Îsâ ibn Sawrah ibn Mûsâ ibn al-Dlahâk. al-Jâmi al-Kabîr Sunan al-Turmudzi. Bayrut: Dâr al-Gharb al-Islâmî. Muhaqqiq: Basyâr 'Awad Ma'rûf. (w. 279 H), (1996)

Zarkalî. al-, Khayr al-Dîn ibn Mahmûd ibn Muhammad ibn 'Alî ibn Fâris. al-A'lâm. t.t.: Dâr al-' Ilm li al-Malâyîn. 2002. 
Asy-Syari'ah (P-ISSN: 2086-9029 E-ISSN: 2654-5675) is a periodical scientific journal that publishes various results of studies and research, literature review, and other scientific works whose scope covers the field of Islamic law/sharia, law and society in monodisciplinary, interdisciplinary, and multidisciplinary manners. The journal aims to expand and create innovative concepts, theories, paradigms, perspectives and methodologies in the above said scope. The Journal is published twice a year (june and december) by Faculty of Shariah and Law, Sunan Gunung Djati State Islamic University Bandung in collaboration with Asosiasi Sarjana Syariah Indonesia (ASSYI).

\section{EDITORIAL OFFICE:}

Fakultas Syariah dan Hukum UIN Sunan Gunung Djati Bandung J1. Raya A.H. Nasution No. 105 Cibiru Kota Bandung, 40614

Tlp/Fax: +022-7802278 Faks. 022-7802278

Website http://journal.uinsgd.ac.id/index.php/asy-syariah/index

E-mail: Jurnalasy-syariah@uinsgd.ac.id 